\title{
科 学界动态
}

\section{关于中國近代史分期問題的討論}

\author{
荣 孟 源
}

（中国科学院歷史研究所第三所）

中國近代史分期問題顼在所討論的是旧民主 主义革命时期，楑据什么标准來分期和如何分期 的問题。

仴頪同誌的“中國近代愿史的分期問題” (“㦄 史研究” 1954 年第 1 期)一文, 是討論这个問題的

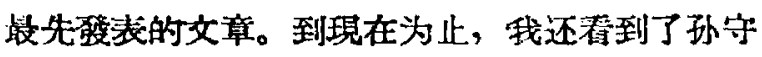
任同志的“中國近代厢史的分期問題的商推” (“歷 史研究” 1954 年第 6 期）、金冲及同志的“对于中 图近代歷史分期間題的意見” “厢史研究”1955年 第 2 期)、范交孄同志的“中國近代史的分期問题”

(“中國科学院磨史研究所第三所集刊”第 2 集)

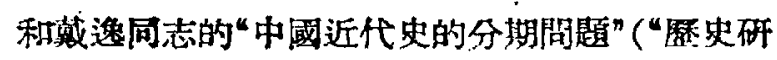
究” 1956 年第 6 期）等四篇交章. 先抄錄各家的 㩆法如下:

\section{一 分期的标准}

1. “基本上用階敉斗争的淩現來做划分时期 的标志。”一胡粗

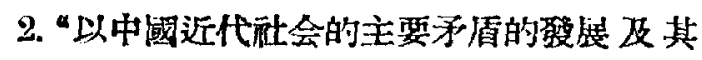
宣的某些变化为标准。”一孙守任

3. “分期的标准应該是将社会經济（生圱方 式）的表征和階般斗笔的表征結合起來若察，以 战出中国近代原史过程發酸各个階段中的具体特 点。”-金冲及

4. “依据”被根本矛盾所規定或影响的部多太 小预盾中，有些激化了，有些是㜞时地或局蔀地 解决了, 或者緩和了, 又付些晨受生了”(“毛溜 东选集” 2 管 780 頁）的原理，來看这80年歷史的

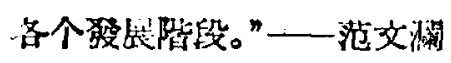

5. “用階級斗争作为中國近代洖的分期标 准。”一戴魀

\section{二 分期的具体意見:}

1. 分七个階段一一胡㮀

(1) 1840 年到1850年，“这是中國由封建 社会开始轉变为坐殖民地牛封建社会的时期。”

（2）1851 年到1864年，山國近代史中第一次 革命运动高镸时期。（3）1864年䟝1895年，“这 是中國牛殖民地牛封建的新会和政治形成的时 期。”（4）1893 年到1900年，中国近代是中第 二次革命运动到㜊时期。（5）1901 年到 1905

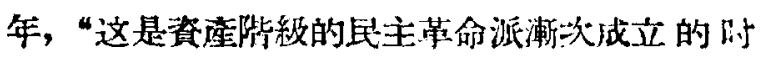
期。”（6）1905 等到1912年，中國近代史中第 三大革命运动高拈时期。（7） 1912 年到 1919

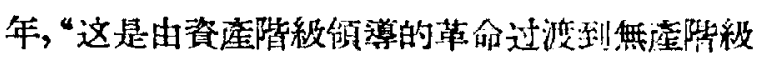
颃港的革命的时期。”

\section{2. 分四个階段一孙等作}

（1）1840 年到1864 年，“自由资本义时

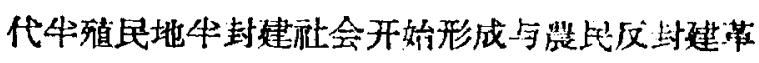
命的高涱期。”（2）1864年到1894年，“自由凅

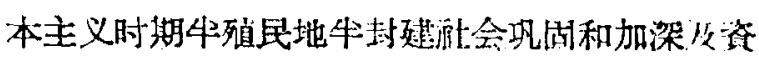

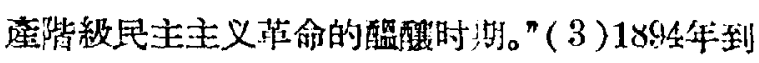

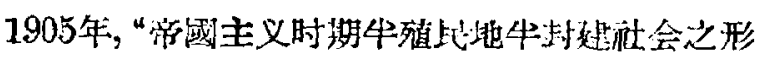

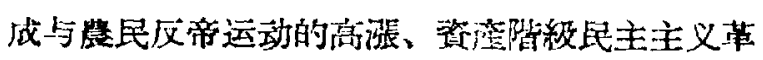

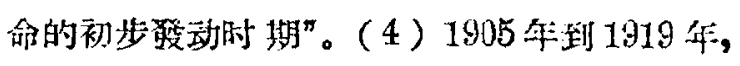

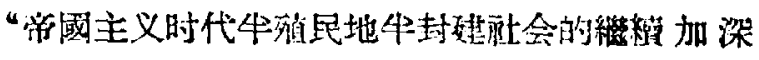

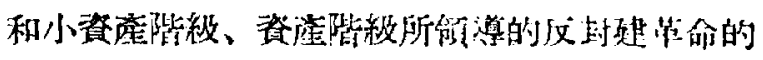

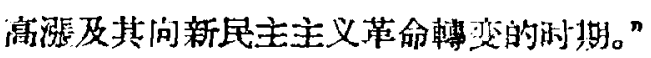




\section{3. 分五个階段一金冲及}

（1）1840 年到 1864 年，“这是中國由封建

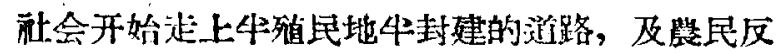
封建运动湖张时期。”（2）1864. 年到 1894 年， “这是的國牛殖民地牛封建拄会逐步形成, 及反动 統治秩序整时稳定时期。”（3）1895年 到 1800 年，“这是中國牛殖民地生封建社会正式形成，盗

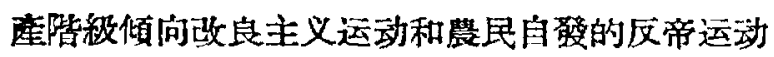
高㤝时期。”（4）1900 年到 1914 年，“这是中國

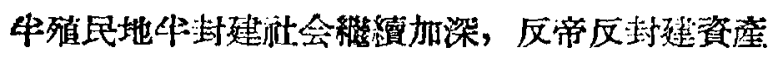
階級星主革命高激时期。”（5 )1914年到1919 年, “这是中國由旧民主主义茧命轉变到新民主主义 革命的时斯。”

\section{4. 分四个階段一漠文瀾}

（1）184:0 年到1864 年，“鸦片战争开始了 中國牛祜是地的原史，太等天国运动（地方性的

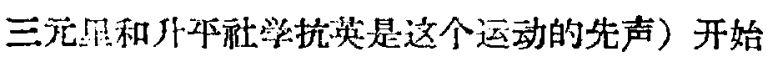

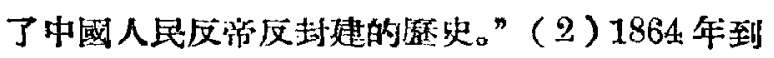
1895年，“封建势力依橖外國的授助，消滅了太平 天国运动的余波，哖朝統治在國內得到整时的稳 定。……可是外國佼略势力公然掠夺中國的澺畂 國, 破坏了这个惓定。”中法、中日“雨次战爭失敗 的結果，帝國主义更樑刻地㻏入中國。”（3)1895 年到 1905 年，“帝国主义經济政治压迫和軍事掠 夺, 以琵关条約为标誌, 以强占靼港为信号, 中 國被瓜分的危机十分臂重。中國人民在这个繁急 关头，激起了爱國救亡运动，在長城以南資倩階

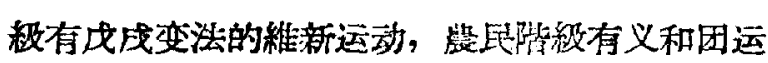
动。……在長战以外，东三省人趾抵抗日本沙俄 兩个帝国主义”，1905 年“中國在日俄战等的刺激 和俄國革命运动的影响下，推动了中國凟原階級 民主革命的前潐。”（4 ) 1905年到1919年，由資应

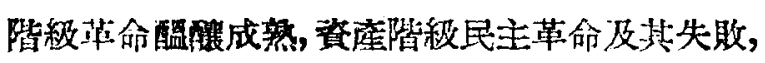
到“旧民主主义革命結束，中國革命晌新民主主义 革命过渡的階段。”

\section{5. 分三个階段一一戴逸}

（1）1840年到1873年，是蓝命形势第一个 階段。“这个草命形势的基本特点和封趣社会稀來

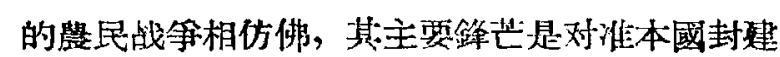

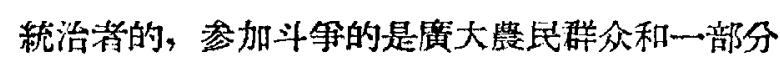

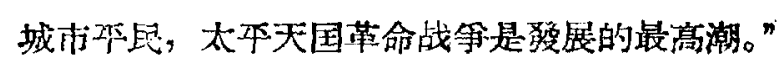

（2） 1873 年到 1901 年，是革命形势第一个階

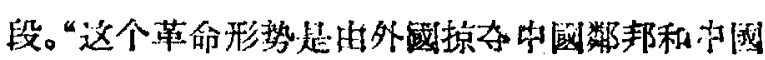

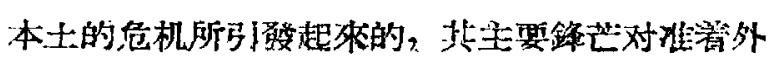

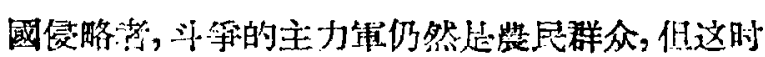
已能看到微弱的资陵階級改良主义政治运动。义

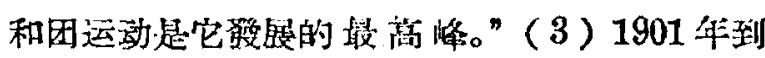
1919 年, 是革命形势第三个階段。“这个革命形势

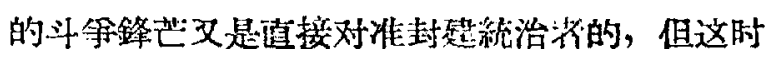
的封建統治著已經徽底变成帝菏主义侵略中國的 工具, 所以这个斗等归根到成文必然是于丁方究国

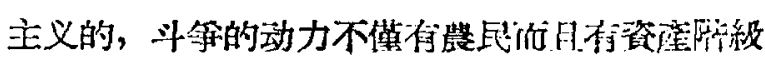

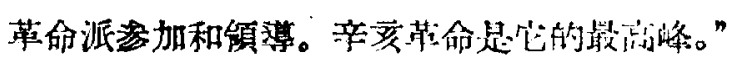

\section{$\equiv$}

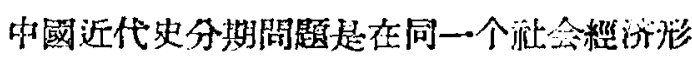

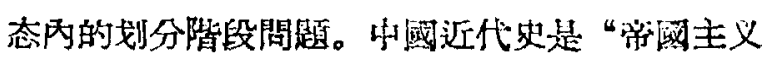

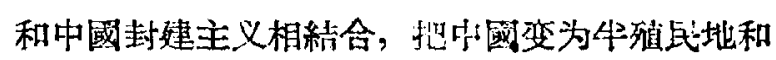
殖国地的过程，也就造和国人民反抗帝國主义及 其走狗的过程。“(“王罣东选集”整 2，602员)这

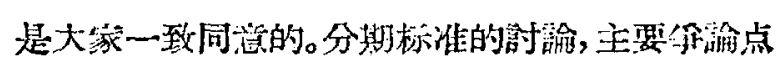
是以階級斗争为标准还是以主要孜卢的变化为标

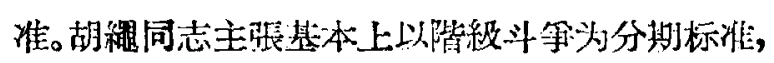

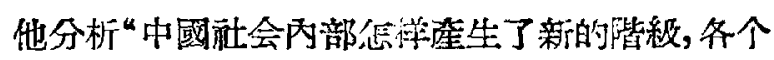

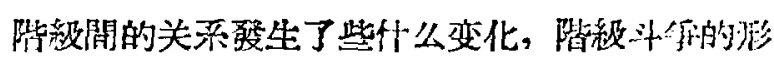

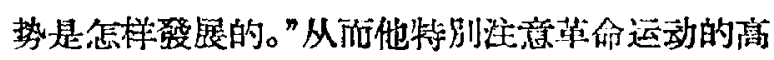
浸时期，因为那是 “能会力量的新的配备通过湤

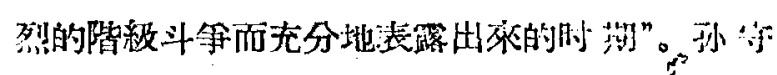
任同点主張以主要矛盾的变化为分期标谁，他觉

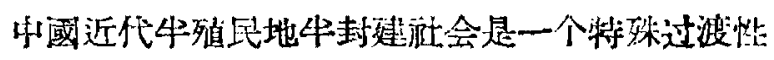

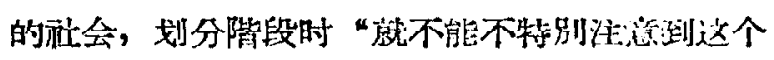
注会的性質上的某些变化，陵級斗争恢望上的某 些变化, 而不能只拿溜粄斗争的高潮和低湖做标

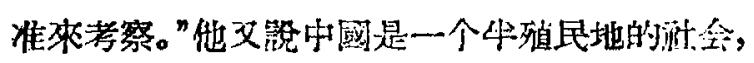

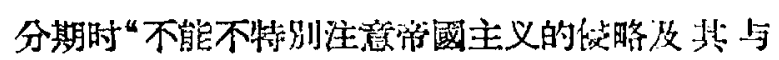

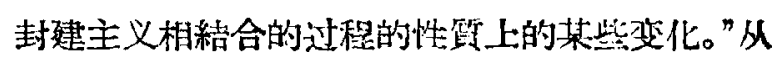
而他提什中国近代史上三种主姴腬原的形式：第

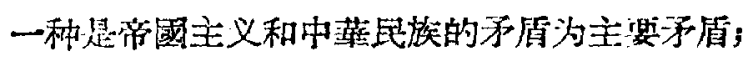
第二种是封建主义和人民大众的矛盾为注要矛 盾; 第三种是外國常国主义和國队反动派赔在一

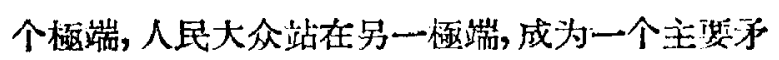

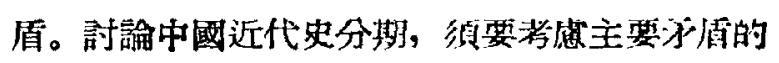
变化，但是近百年本中國㼛会性質的变化，在中

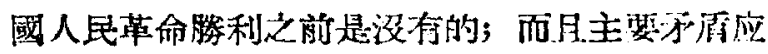


鿁是階㿮斗爭, 以主要予盾为分期标准的镜法,

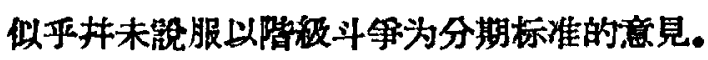

\section{四}

关于划分階段的具体意見，爭諭很多，僅錄 其主要的問題如下:

第一个問題是中國近代史第一階段为 1840 年到 1864 年抑为 1840 年到 1873 年的問題。戴逸 同志主张第一階段应划在 1873 年, 其理由是: 太 平天国茫命失敗之后，捻軍、回民、苗民起义一

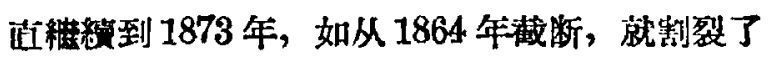
近代亚民战爭的整体。在人民大学討論戴遏同志 的論交时, 許多人不同意这样的分期, 而主張以 1864 年为下限。其理由是 1864 年天京陷落, 太 平天国失败，标志者革命政权的失敗，票民战孚

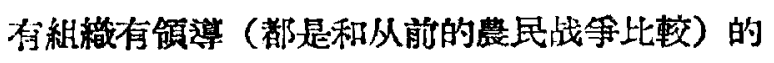
力量被刢減; 第二次鴉片战爭所訂的条約实現, 中國酷会更進一步地殖民地化; 六十年代以后，國

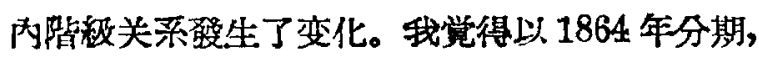
理由似尤足一些。

第二个問題是 1894 年或 1895 年是否可以分 期的問題。孙守任同志說, 1894 年以前是自由資 本主义时期, 以后是帝國主义时期。金冲及同志 欲到 1895 年以后的特征时也特別提出, “國际資 本主义進入帝國主义階段”。范文洞同志筑，甲午 战争失敗, “帝國主义更深刻地長入中國, 表現为 第三时期瓜分中國的狂安企圖”。十九世紀尔叶國 际资本主义到帝國主义階段，这是事实。甲 千午日战等以后，帝國主义更深刻地侵入中國， 瓜分中國的质机追在有曃，激起中國人民的反抗， 这也是事实。但是只就这一面的事实來分期，而忽 視了甲午战争前后國內階极关系是否發生多大的

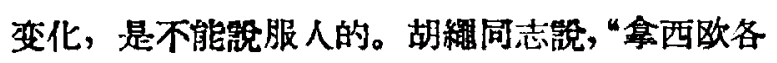
國份末進入帝國主义階段作一个时期, 而在進入 帝國主义階段后作为另一时期”, 是不恰当的。“誠 然，在牛殖民地牛封建的中國，外國帝國主义的 嗦略对于中國社会歴史進程起了很大的作用, 但

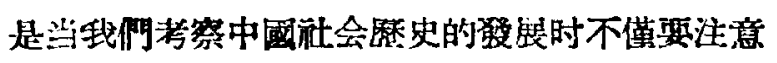
外淢势力怎样來侵略, 而且更重要的是注億中國 民对于外國势力的侵略表現了怎样的反应。”戴 逸同志也不同意按甲午战争前后來分期，他疑这 样分期有雨个缺点: “第一是忽略了長期皘然起呠
的反数会斗学与义和团运动之間的联系性, 从六 十年代以后，反数会斗爭此起彼代，成为本时期 內人民力量的主要表現，义和团运动正是这种斗 争的㕍集和栈繶。” “第二是忽略了中法战争、中 日战争和义和团运动三次民族战爭之間的共间 性, 这三次战爭同样都是反对外國侵略者夺取中 國梀邦和領土，亦即反对外國侵略者分割殖民地 的战争，其反面都不同程度的带有帝國主义侵略 战爭的性質。”我地不䁈成以甲午中日战争來分 期的意見，抹再补光一点理由: 甲午中日战争前 后, 中國社会階級力量的配备浔有顯著的变化; 甲午以前的維新运动和伐线变法是不便从中琙断 的。

第三个問題是 1900 年或 1901 年是否可以分 期, 1895 年到 1905 年是否成为一个階段的問超。 玿守任同志和范交瀾同志都主張 1894 年 或 1895 年到 1905 年为一个階段。孙㑏任同志锣: “甲午 战争标志着帝國主义性筫的侾略开始占了主導地 位，标志着帝國主义用 ‘战争的’ 方式代替了“温 和的”方式。中國社会主要预原形成了第一种形 式，一直延艘了十年以上。”这样的筑法不能使人 心服。第一，从鴉片战爭到八國联稙之役，嵃國 主义对于中國進行了五次侵略战争，第二次雅片 战争到中法战争为十四年，中法战手到中日战等 为十年, 在甲午战争以前，資本主义列强对中國 的侵略, 何尝是 “温和的”方式; 因此所謂甲午战 争后“帝國主义用 ‘战争的” 方式代替了“温和的” 方式”論据不足。第二, 如果锐帝國主义性質的依 略是以㾞本签出为主, 甲午战争以后帝國主义大 量向的國投資，划分势力范图，進行瓜分中國的 除謀活动。1900 年到1901 年义和团运动之后, 沙俄、日本和美國帝國主义仍是稵繥以武力争守 瓜分东三省。但是不能忘記，义和团反帝运动迫 使帝国主义不得不整时收起瓜分中国的野心，在 長城以南各帝國主义暫时維持相互間矛盾的現 狀, 保持自己的势力范睘, 这十年間帝國主义㻏 略中国的情况是不相同的。如果从階般关系方面 來看, 义和团运动以后, 帝國主义整时收起瓜分 中國的野心，通过中國封建势力來压迫和剝牦中 國人民; 清朝政府在八國联簐，之役以后，䚄全投 靠帝國主义棑維持自己的反动統治，清朝政倠成

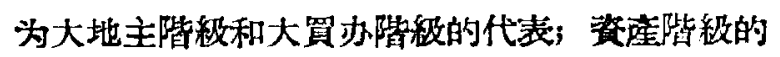


民主主义革命运动代替了改良主义运动成为政治 斗争的主流; 自受的莀民运动基本絬束，以后宸民 运动和資倩階极的民主草命开始强生联系。根据 这一些特佂, 可以从 1901 年分期。1905年階級变 化汥有颖㦈的特征，似不便分期，从而1895 年 到 1905 年也不能战为一个階段。

第四个開趐是辛要革命以后是否划分为一个 階段以及如何划分的問題。胡鷥同志镜，“从1912 年到 1919 年，即从装亥革命失敗后到五四运动。

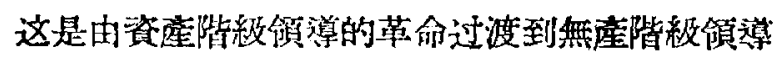
的资合的时期。”金冲及同志視: “从1914年到1919 年，这是中國由旧民主主义革命轉变到新民主主 义革命的时期。”戴逸同志反对在㳯要革命后另分 一个时期，他䇴：“因为 1912 年固然标志着旧式 資道階級民主革命的破虐，但是在这以后六、七 年》，革命裙仍在旧民主主义的革命淔路上摸索 前進。如韸蜜之役、反袁之役、护法之役, 这都

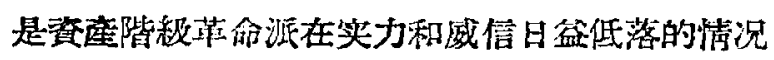

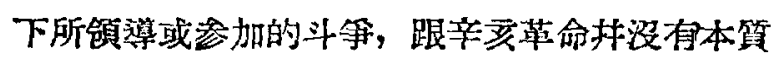
的差別，因此这个階段基本上仍屬于第三个革命

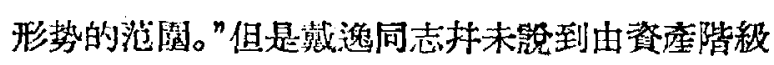

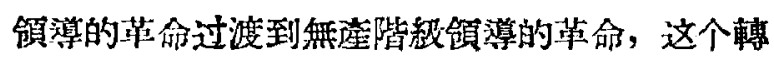

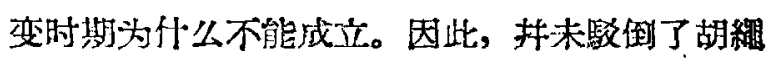
同志和金独及同志的意見。辛严革命失敗后到五 四运彷这一段曆史，是旧民主主义革命过渡到新 民主主义革命的歷史，我認为这个过渡时期，可 以独立为一个階段。

以上介紹了同志們对于中圆近代史分期的意 見, 如舆介紹錯了，与原作者無关，那是我的杢

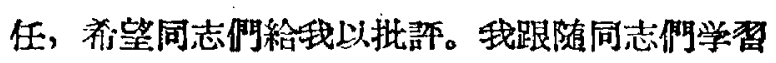
分析中國近代史分时閔題, 自己的一点意見也願

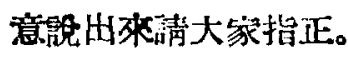

\section{五}

有人證，中國近代史的断限应从 1840 年起, 到 1949 年 9 月此。我䧼成这个意見。从鴉片战争

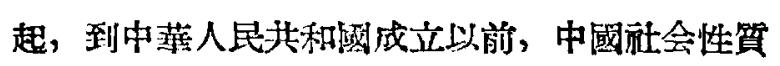
是一个牛殖民地牛封建社会, 中國革命性筫是民 民主义革命, 这 110 年的歷央应該作为一个有 时期, 以做洔國近代史。假如从新民主主义革命 起到目峛作作为現代史, 那么所部近代史只是牛 㥀民地平站建社会愿史的一牛，而現代史却包括
着中烡人民共和成成立前后兩个不同性質塥会的

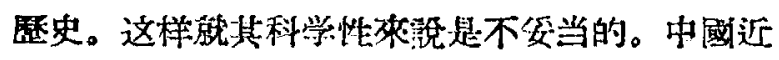
代史应当分为但主主义革命和新民主主义莒合 丽个时斯。从前, 特别是在 1949 年以前, 我們把 新民主主义革命时期做为現代史，把昍民主主义 革命时期做为近代史，那时中國符会性筫没有改

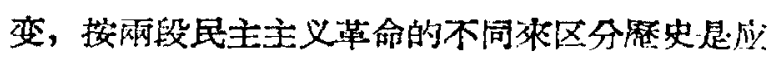
辟的。但在今天中國人民民主革命胘利之后，中 國社会性筫已經改变, 中國革命性筫改变了, 性 保守着旧日的样子划分整史階段就不公当了。

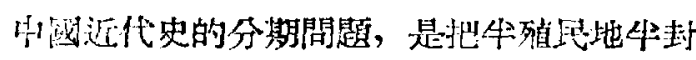

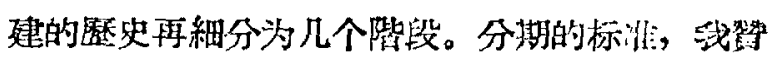

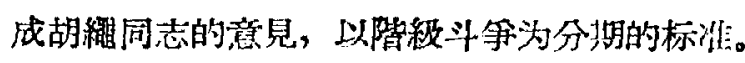

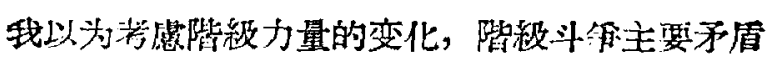
的变化, 甜國近代史可以做这样的分期:

第一倩段从 1840 年到 1864 年。

雅片战争开始了中國牛殖民地的嵟史，也开 始了小國人民反帝反封建斗学的歴史。牛殖比地 牛封建社会开始，社会性算和雅片战争以前的椡 建社会不同了。但是这一时期中國还沒有代現新

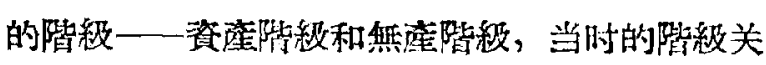

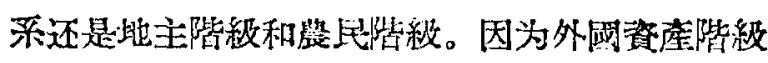
侵略中國，引起了地主階級和唯民階級力息的变 化，也引起了階級斗等主要矛盾的变化。

这二十五年中，歴史上待雨次对外战争（雅 片战爭和英法联軍之役）和一次太本天国革命。 从呀片战爭起地主階級就开始了变化，少数的官 僚地主如林則徐、魏源、溤桂䒺等开始要向資本 主义國家学習，这一派后來桴展成为維新派; 另 有一些官僚地主开始勾結外國侵略者，在英法联

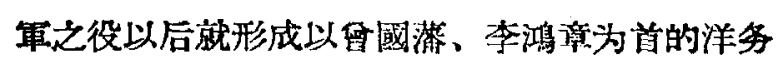
派; 以清朝政府为代表的地主階級开始问外琙侵 略者投降，英法联軍之役以后勾結外國侵略渚來

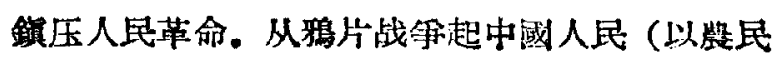
为主体) 开始了反帝斗爭, 凡是侵略軍所到的地 方，当地人民都群起反抗，廣东三元里本英团的 抗英斗学影响龙大; 太平天国革命主要是鹿明反 封建的革命运动, 可是也担負起了反抗外國侵略 者的任务。这一时期中國形会的跂主要的矛盾是 人民大众和封建主义的矛盾，但是中國人民和帝 國主义的矛盾地成为主要歌盾了。

第二階段从 1864 年到 1901 年。 
这一时期有三次对外战争（申申中法战等、 甲午中日战争、八国联軍战争)，一次戊戌維新运 动、一次义和团反帝运动。在这一时期中中國出

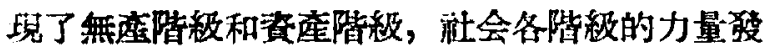
生了变化。帝國主义侵略势力在第二次鸺片战等 以后，日篮深入，到了甲午战争以后，竞婪想瓜 分中圈。封建地主階粐的一榊分灰当帝國主义的 買办，形成为洋务派，他們是清朝封建統治的重 要交柱。由于太平天国革命打陆了清朝的封廷統 治，所以太本天国革命运动以后中成民族资柱

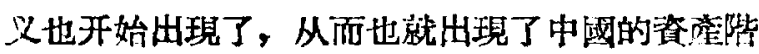
耕。但是这个階級力量非常微强，而目和卦建势

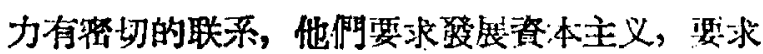
实行民主政治，望求民族独让，可起他們人数很

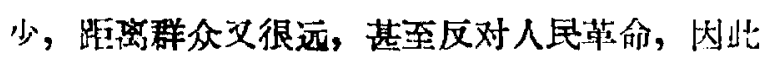
他們不㴰也不敢萑命，只能進行維新运动，希些

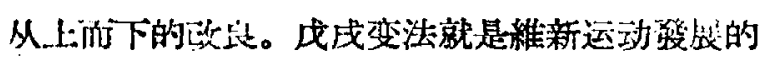

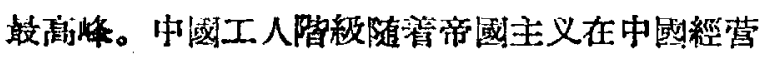
企業，随清洋务派經营官办工業就出現了，他圵

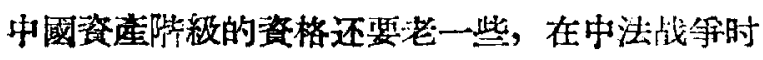

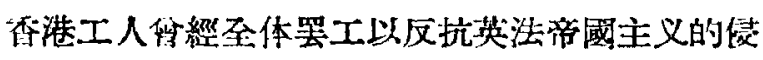

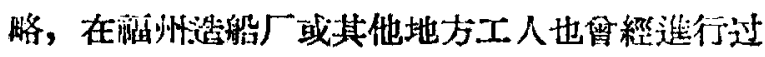

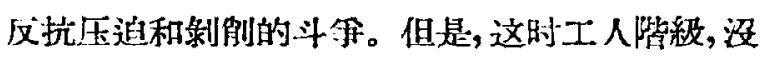

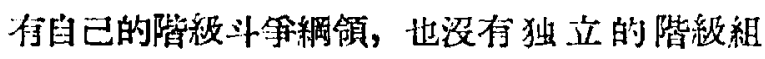

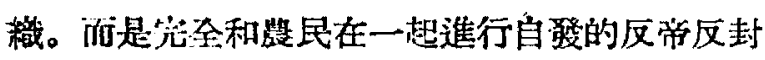

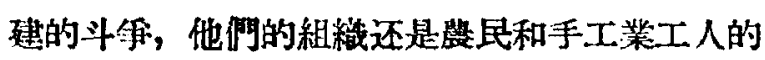

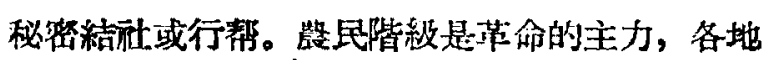
小規模的起义以及义和团反帝运动都是以繁民为

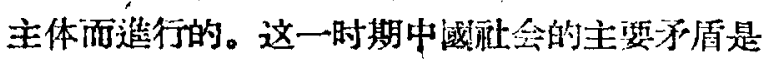
中國昌族和管國主义的矛盾，三十几年中几百起 的数笔，是人民反对帝國主义利用宗教侵略的反

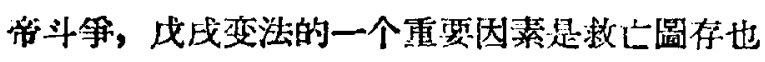
是反帝斗争，三次对外战争是反演斗尔，义和团 反帝运动更是普及于全國的反策斗称。

第三些没从 1901 年到 1913 年。

这一时期的主要愿史事件是辛莨茧命。这十

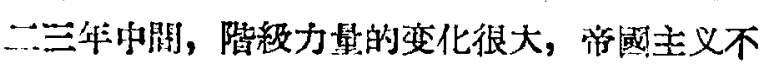

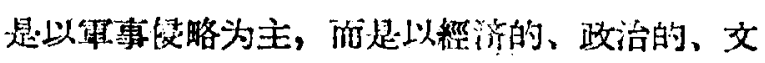
化的伎略为主，所以中國队蔀的斗孚也就特別尖

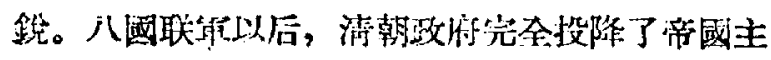
义，和从前'的絬渧國主义程压革命不同，而是依

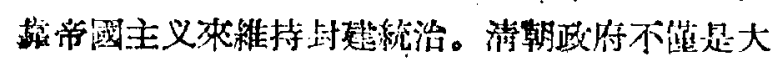

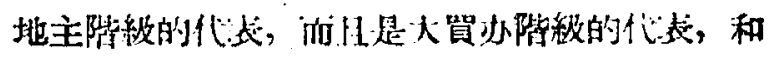

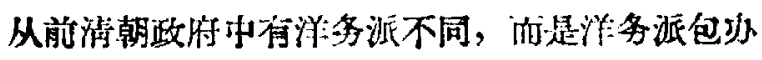

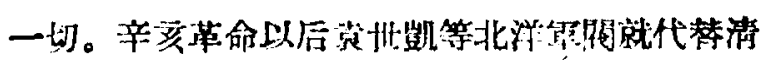

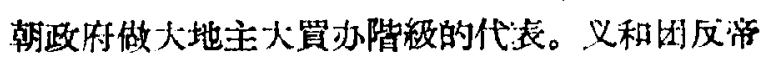

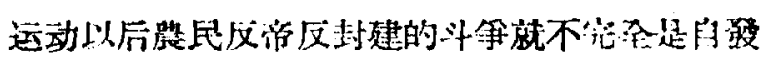

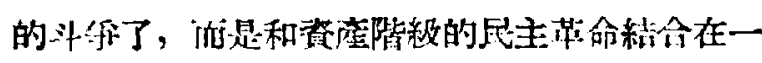

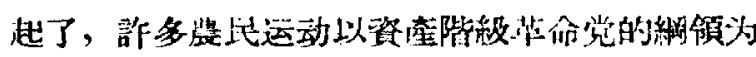

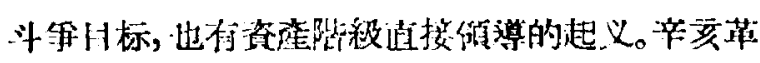

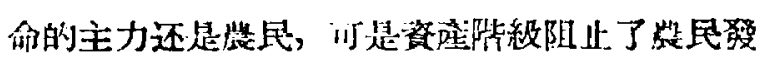
一揮革命力量。工人階級在义和团运动以后，力量垤

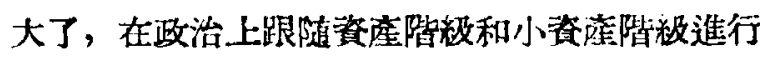

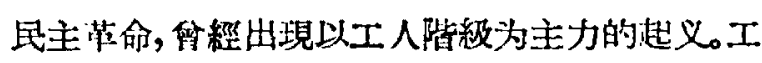
人自登的經济斗等增加了，㩲大了，名义上的“工 会”、“工党”（丝边包括工人和盗本家）也出现了。 辛黃革命前后，因为工人力转的此大，所以有一些

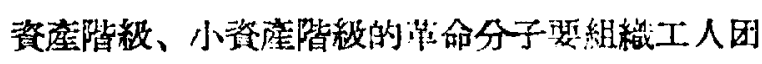
体，也有投机的官僚政客企闾利朋工人法体的名

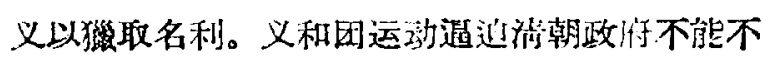
变法，周然这个变法是假的，但测䖽中國资本 主义的登展造成了一侦伐利的条件。因此，这时 凟倩階释比以前些大一些。义和团运动以后, 中

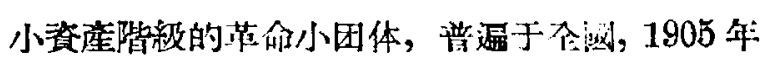

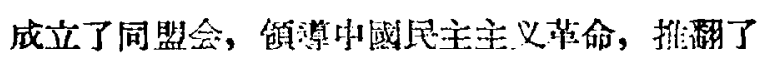

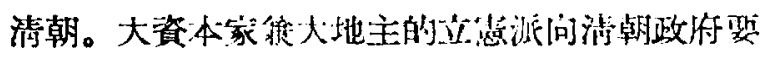
求民主，也反对裔国主义的你略，叮从是他們反对 革命。在辛亥落命的浪湖中他們参加了篗命，和

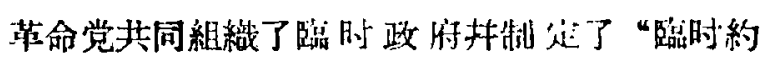

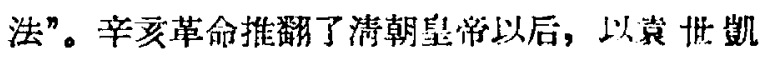
为中心，帝国主义、入地主階䄲、大置办陟被和

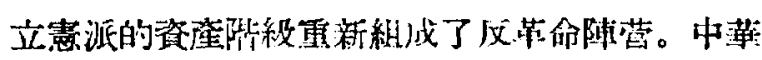
民國只是形式上的民主共和国。这一时期最主要

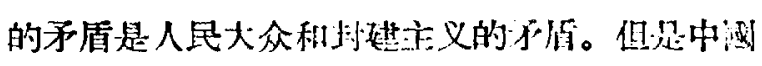

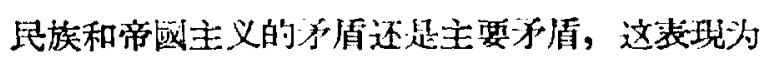

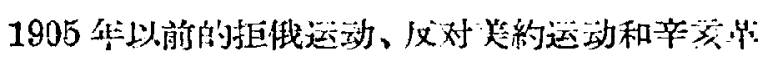

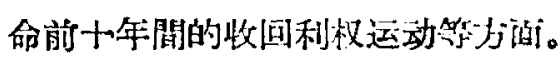

第四階段从 1913 年到 1921 年。

这一时期的主要歷史事件是五四运动。由于

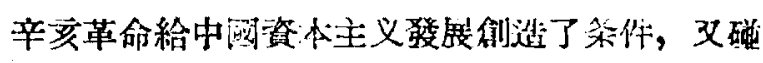

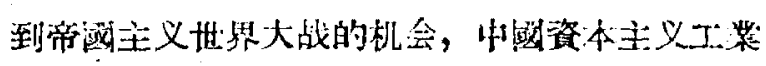

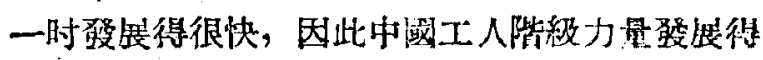

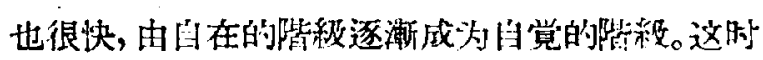

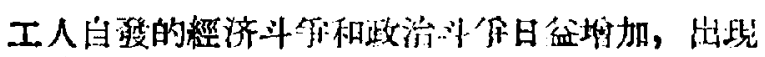


了类乎沂代工会似的工人团体。1917年俄國十月

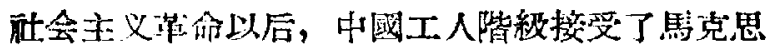
列畐主义。在五四运动中，中國工人階級成为中 坚的革们力量。到了1921年7月就組成了中國共 厓党，中國共党成立以后，工人階煞就成为中

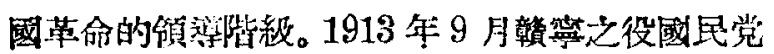
失敗上后，以國民党为代表的資㟲階級被北洋簐

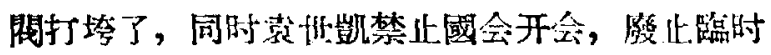
約法，把以造步党为代婊的資视階級排挤了。具 有資险所級民主共和國性筫的政权从此絬桨，此 后虽然保凪着“民或”的名义，实質上却是以北洋 軍閣为代㳀的大地主和大買办的封建整制。他們 和清朝政拊的区別, 是在于北洋軍闻的賀办性更 大一些。这时進步党和國民党算經進行过“护國” （护辛药后的民主共和國）和“护法”（护臨时 約法）的头等，但是都失敗了。他們都不能領等 革命。这时提出了“民主和科学”的民主主义口

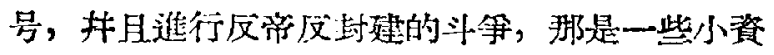

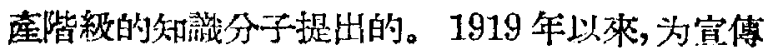
“民”主和科学”思想们奋斗的中坚力量是初步接受

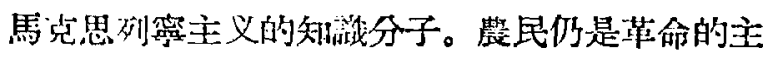

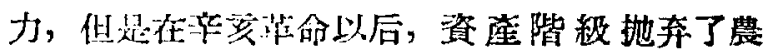

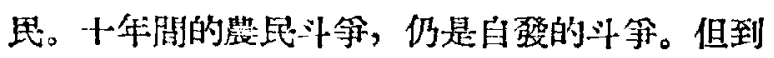

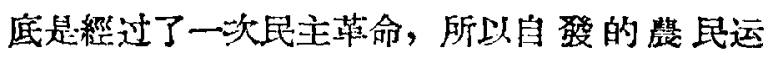
动，也标示篦民主主义的口号。这一时期欧洲帝 國主义的渎略力量相对地縮减了，但日、美帝國 主义能㮹略势力却摬大了。特別是日本提出“二 十一条”, 使中國陷于淪为殖民地的險境。因此, 中国族和常國主义的矛盾成为最主要的矛有, 反对“二十一条”成为斗筝的中心閏題，从 1915 年 开始，到了 1919 年还是以“二十一体”为導火桡 爆了五四运动。人民大众和封建主义的矛盾仍

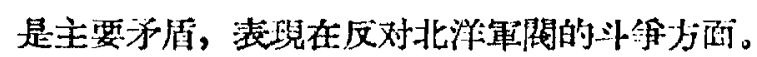
中國新民主主义落佮 正式 开站于1921 年7 月中國共鉴党的成立。新民主主义草命䯅主安的 特征，是工人階級的颃集。五四运动是辛严革份

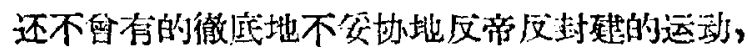
但是五四爱國运动护沒有正式提证㴖命的政治紨

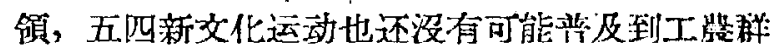

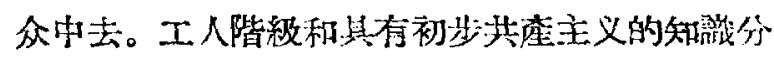

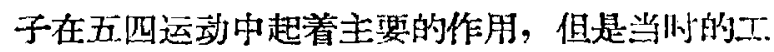

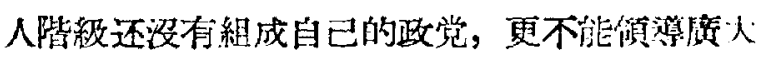
的群众組糡。1921年中國共应党成直以后，掅况 能不同了, 中國革命的絧領是由工人階䄲提代而i 为全國人民所拥护的，中國萍命的斗等是怕工人

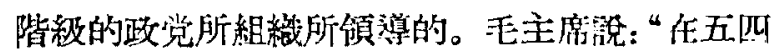

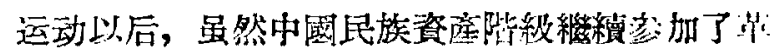

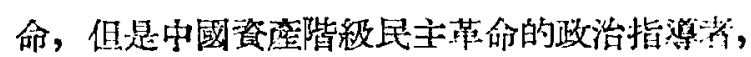

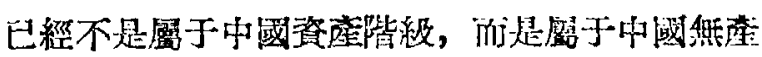

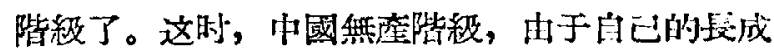
和俄國革命的影响，已經迅速地变成了一个敩㤳 了的独立的政治力量了。打倒常國主义的口号和

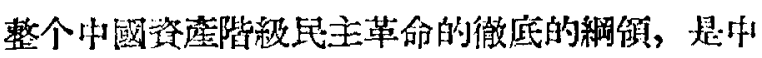
國共应党提出的; 而土地革命的实行, 則赶中國然

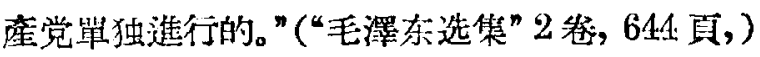
中國共産党的成立，是中國新民主主义雚命正式 开始，从 1921 年到 1949 年，中國近代史新民主 主义革命时期可分为四个階段，即: 1921 年到 1927年第一次國內革命战爭；1927 年到 1937 年 第二次國內革命战争；1937 年到 1945 年执日战 争; 1945 年到 1949 年第三次國队革鸽战争。因 为現在討諭的是中國近代史旧民主主义革命时期 的分期問題，新民主主义革命时期各階段的特点 就不必多镇了。

\section{中國自然科学史第一次科学討論会}

中國自然科学史研究委員会于7月9-12日 举行了第一次科学討論会, 出席和列席这次会㦈

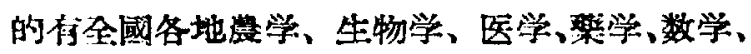
天文学、歷史学、考古学和哲学等方面的尃家和 研究工作者共 120 人。在会議第一天, 些仃楨副
院長作了題为“百家学鳴和筑珽毛國古代科学造 厓”的报告。他可用我國古代科学的偉大成就來 諭証研究自然科学史的重要意义。他镜: 䃑究工作 者应該正确地估計中國民族在世界文化史上所占

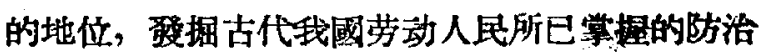

